Original Research Paper

\title{
Pengembangan Usaha Penggemukan Sapi Rakyat Berbasis Kemitraan dalam Upaya Pemberdayaan Landless Farmers di Kecamatan Narmada Kabupaten Lombok Barat
}

\author{
Lalu Wiresapta Karyadi ${ }^{1 *}$, Lalu Ahmad Zaenuri ${ }^{2}$, Lukman HY², Lalu Wira Pribadi² \\ ${ }^{I}$ Fakultas Pertanian, Universitas Mataram, Mataram, Indonesia \\ ${ }^{2}$ Fakultas Peternakan, Universitas Mataram, Mataram, Indonesia
}

DOI: https://doi.org/10.29303/jpmpi.v4i2.808

Sitasi: Karyadi, L. W., Zaenuri, L. A., Lukman, HY., \& Pribadi, L. W. (2021). Pengembangan Usaha Penggemukan Sapi Rakyat Berbasis Kemitraan dalam Upaya Pemberdayaan Landless Farmers di Kecamatan Narmada Kabupaten Lombok Barat. Jurnal Pengabdian Magister Pendidikan IPA, 4(2)

\section{Article history}

Revised: 20 Mei 2021

Accepted: 21 Juni 2021

*Corresponding Author: Lalu Wiresapta Karyadi, Fakultas Pertanian, Universitas

Mataram, Mataram, Indonesia; Email:

wskaryadi21@gmail.com
Received: 23 Maret 2021

\begin{abstract}
Kegiatan pengabdian kepada masyarakat ini bertujuan untuk mengenalkan para petani/peternak dengan berbagai pola kemitraan dalam mengembangkan usaha penggemukan sapi rakyat berbasis kemitraan sebagai alternatif income generating bagi kalangan Landless Famers, serta untuk menggalang kelompok-kelompok usaha penggemukan sapi berbasis kemitraan di Desa Peresak Kecamatan Narmada Kabupaten Lombok Barat, NTB. Kegiatan dilaksanakan dalam bentuk penyuluhan dan pendampingan disertai upaya penggalangan kemitraan. Sasaran kegiatan, adalah petani/peternak berlahan sempit dan para buruh tani, keseluruhannya berjumlah 85 orang. Hasil evaluasi kegiatan menunjukkan, pola-pola kemitraan dalam penggemukan sapi telah dikenal para peternak, diantaranya adalah pola bagi hasil. Pola ini dikenal oleh seluruh $(100 \%)$ peternak sasaran kegiatan. Pengetahuan dan informasi yang disuluhkan, sangat membantu para peternak dalam mengatasi permasalahan rendahnya peluang kerja bagi masyarakat, serta dapat mengembangkan usaha penggemukan sapi rakyat dengan sistem bagi-hasil. Sebanyak 61 orang $(71,76 \%)$ peserta sasaran menyatakan ketertarikan dan kesediaan untuk mengembangkan usaha penggemukan sapi dengan pola kemitraan. Dari jumlah tersebut, tercatat 28 orang $(45,9 \%)$ telah menggalang usaha penggemukan sapi dengan pola bagi hasil.
\end{abstract}

Keywords: Penggemukan sapi; Pola kemitraan; Landless farmer; Income generating; Penyuluhan.

\section{Pendahuluan}

Sebagaimana diketahui, bahwa permasalahan utama pembangunan nasional selama ini adalah bagaimana meminimumkan jumlah penduduk miskin, terutama kemiskinan absolut. Menurut Bamualim (2012), walaupun berbagai program pembangunan telah dilakasanakan namun masih banyak penduduk yang berada dalam keadaan miskin, sebagian besar dijumpai di wilayah-wilayah pedesaan; mereka menggantungkan hidupnya terutama pada usahatani tradisional.

Para petani miskin pada berbagai wilayah pedesaan di Indonesia, termasuk di Nusa Tenggara Barat, pada umumnya merupakan petani yang tidak memiliki lahan atau ternak atau merupakan petani dengan lahan usahatani sempit -luas lahan garapan rata-rata hanya 0,17 ha (Zaini, 2008)- sehingga disebut Landless Farmers. Dalam keadaan demikian, mereka sulit memperoleh pendapatan guna menghidupi keluarga (Simatupang, 2013). Oleh karena itu perlu dipikirkan upaya yang relevan 
guna meningkatkan pendapatan dan taraf hidup Landless Famers tersebut.

Salah satu gagasan yang dipandang perlu mendapat perhatian, adalah pengembangan cabang usahatani dengan pola intensif (non land base) berupa penggemukan sapi. Pengembangan usaha ini biasanya terkendala oleh keterbatasan modal, khususnya modal untuk pengadaan sapi bakalan yang diperlukan. Kendala dimaksud merupakan masalah yang perlu dicari jalan keluarnya.

Pengembangan usaha produksi sapi potong (penggemukan) di kalangan Landless Famers dapat ditempuh melalui penerapan strategi kemitraan, dalam hal ini, petani/peternak yang memiliki modal keterampilan beternak sapi potong dapat menjalin kemitraan dengan pihak-pihak tertentu yang memilki modal finansial untuk pengadaan sapi bakalan. Kemitraan antara petani/peternak dengan pihak penyandang modal tersebut dapat diaktualisasikan dalam suatu sistem bagi-hasil, sebagaimana telah berkembang selama ini di NTB, khususnya di Pulau Lombok.

Strategi kemitraan dengan sistem bagi-hasil menunjukkan hubungan antara pemilik atau pihak/orang yang menggunakan (tanah, ternak, tanaman, dll.) dengan penggarap/penggaduh dan merupakan suatu bentuk usaha yang tidak mengeksploitasi sasaran usaha (Scheltema, 1995). Dilihat dari sudut ekonomi dan hukum, bagi hasil usaha ternak dapat berupa perjanjian upah, sebagai suatu bentuk perseroan, atau keduanya ; pada bagihasil usaha tambak akan ditambahkan lagi perjanjian sewa tambak.

Sistem bagi-hasil yang banyak dijalani kalangan Landless Famers di Pulau Lombok, adalah sistem bagi-hasil dengan pola tradisional yang mendasarkan pada pembagian sama basar (50 : 50) terhadap pertambahan nilai modal (capital gain) sapi bakalan yang diusahakan. Pola demikian diketahui lebih menguntungkan bagi petani/peternak penggaduh dibanding pola bagihasil yang berkembang di daerah-daerah lain seperti Pola PIR di Bali yang mendasarkan pada pembagian nilai pertambahan bobot badan sapi (weight gain) $2 / 3$ untuk penggaduh dan $1 / 3$ untuk pemodal (Lole dkk., 2004). Pada bagi-hasil pola tradisional, pendapatan petani/peternak penggaduh diperoleh tidak saja dari weight gain tetapi juga dari capital gain berupa pertambahan harga murni (PHM) dan kenaikan harga karena peningkatan kualitas (PHK). Sedangkan pada Pola PIR, semua
Capital gain hanya dinikmati inti, padahal capital gain tersebut diperoleh ketika ternak dipelihara petani/peternak penggaduh (plasma).

Setiap pola bagi-hasil dalam usaha penggemukan sapi yang berkembang selama ini di Pulau Lombok diketahui sangat bermanfaat bagi kalangan Landless Famers, terutama dapat memberikan tambahan pendapatan (income generating) bagi keluarga mereka. Hal ini terlihat antara lain dari hasil penelitian Sulmawaty (2018), bahwa persepsi peternak terhadap sistem bagi-hasil dalam penggemukan sapi di Lombok Tengah adalah sangat positip, dalam hal itu, peternak penggaduh dapat memperoleh tambahan pendapatan rata-rata $\mathrm{Rp} 300.000$ per bulan dari setiap ekor sapi bakalan yang diusahakan.

\section{Metode}

\section{Sasaran Kegiatan}

Khalayak sasaran kegiatan ini adalah para petani/peternak yang diketahui tidak memiliki lahan usahatani sendiri dan petani/peternak dengan lahan usahatani sempit, yang pada umumnya digolongkan Landless Famers di Desa Peresak Kecamatan Narmada, Kabupaten Lombok Barat. Jumlah petani tanpa lahan (buruh tani) di desa Peresak tercatat sebanyak $996 \mathrm{kk}$ dan petani berlahan sempit sebanyak 711 orang, sehingga jumlah Landless Famers yang dapat menjadi sasaran kegiatan ini adalah sebanyak 1.707 orang.

Adapun sebagai khalayak sasaran antara yang strategis, diambil 5\% dari jumlah Landless Famers yang ada, yakni sebanyak 85 orang. Jumlah ini diambil secara proporsional dari semua dusun yang ada di desa Peresak. Jumlah terbanyak, yaitu 32 orang $(37,65 \%)$, berasal dari Dusun Tebao. Hal ini berkaitan dengan paling tingginya jumlah peternak sapi di dusun ini dibanding dusun-dusun lainnya di desa Peresak. Adapun jumlah peternak sasaran dari dusun-dusun lainnya, adalah: masingmasing 8 orang $(9,34 \%)$ dari dusun Bangket Punik dan Golong, 17 orang $(18,2 \%)$ dari dusun Peninjauan, dan masing-masing 10 orang (12,3\%) dari dusun Punikan dan Peresak Lauq.

\section{Pelaksanaan Kegiatan}

Pengabdian pada masyarakat ini dilaksanakan dalam bentuk Penyuluhan dan Pendampingan disertai upaya Penggalangan Kemitraan. Penyuluhan dilaksanakan dengan 
metode orasi (ceramah dan tanya jawab) dan penyebaran leaflet.

Orasi dan penyebaran leaflet diarahkan terutama kepada para peternak dan pemodal (baik perorangan maupun organisasi/institusi atau badan usaha), juga petugas penyuluh pertanian dari dinas/instansi terkait dan tokoh-tokoh masyarakat serta aparat desa setempat yang menunjukkan kesediaan/ketertarikan terhadap materi penyuluhan. Dipilih waktu pelaksanaan pada sore hari, yaitu saat para peternak tidak bekerja (setelah selesai menjalankan pekerjaan sehari-hari). Pelaksanaan orasi mengambil tempat di Aula Kantor Desa Peresak Kecamatan Narmada, menggunakan media Proyector LCD.

Materi penyuluhan disediakan tertulis dalam bentuk leaflet yang dibagikan kepada setiap peserta penyuluhan. Adapun pembagian leaflet dilakukan sehari sebelum orasi dilaksanakan, dengan disertakan pada surat undangan untuk para peserta. Hal ini dimaksudkan, agar para peserta penyuluhan dapat membaca dan menelaah serta mempertimbangkan terlebih dahulu materi penyluhan tersebut sebelum diorasikan oleh Tim Penyuluh.

Pendampingan dan penggalangan kemitraan peternak dilaksanakan setelah diadakan penyuluhan. Pendampingan merupakan bentuk kegiatan pembinaan bagi peternak berkaitan dengan usaha penggemukan sapi yang dijalankan, kegiatan ini disertai dengan upaya mencarikan/menggalang mitra bagi para peternak yang belum memilki sapi bakalan untuk diusahakan.

Mitra, dalam hal ini, adalah pihak perorangan atau organisasi/institusi atau suatu badan usaha yang menunjukkan ketertarikan/hasrat secara sadar untuk menegembangkan usaha pada bidang penggemukan sapi, dan bersedia bermitra dengan peternak menurut tatacara atau pola yang disepakati bersama. Perorangan atau organisasi/institusi maupun badan usaha yang diutamakan untuk menjadi mitra para peternak sapi di Desa Peresak Kecamatan Narmada, adalah mereka yang pernah terlibat dalam usaha penggemukan sapi, baik secara mandiri maupun kemitraan, di Kecamatan Narmada dan sekitarnya. Penggalangan mitra ini dilakukan oleh tim dengan pendekatan persuasif dan melalui media seminar dan lokakarya (semiloka) melibatkan pihak-pihak pengusaha dan institusi serta instansi terkait seperti
Koperasi Unit Desa, Dinas Peternakan, Perguruan Tinggi, dan lainnya.

\section{Metode Evaluasi}

Evaluasi dilakukan dengan maksud untuk mengetahui tingkat pencapaian tujuan dan manfaat kegiatan yang telah dirumuskan. Sehubungan dengan maksud tersebut, pelaksanaan evaluasi diarahkan pada :

- Perubahan perilaku peternak sasaran (menyangkut peningkatan pengetahuan mengenai mitra dan pola kemitraan dalam penggemukan sapi, serta sikap persepsional terhadap pelaksanaan pola bagi-hasil penggemukan sapi)

- Perubahan jumlah peternak yang mengusahakan penggemukan sapi dengan sistem kemitraan, di desa Peresak Kecamatam Narmada - Lombok Barat

- Respon masyarakat setempat (terutama para peternak dan kelompok-kelompok peternak/usaha penggemukan sapi lainnya di sekitar lokasi kegiatan) terhadap materi kegiatan ini.

Untuk mengetahui perubahan prilaku peternak sasaran, dilakukan evaluasi dengan teknik wawancara menggunakan kuisioner. Sedangkan untuk mengetahui perubahan jumlah peternak penggemukan sapi dengan sistem kemitraan, dilakukan pengamatan secara langsung terhadap peningkatan yang terjadi di kalangan peternak sasaran di Desa Peresak. Adapun respon masyarakat/kelompok-kelompok usaha penggemukan sapi lainnya di sekitar lokasi kegiatan, dievaluasi dengan teknik observasi langsung terhadap berkembangnya usaha penggemukan sapi dengan sistem kemitraan.

\section{Hasil dan Pembahasan}

\section{Pencapaian Tujuan dan Manfaat Kegiatan}

Kegiatan yang dilakukan, berdasarkan hasil evaluasi, telah dapat mengenalkan para petani/peternak kalangan Landless Famers di Kecamatan Narmada Kabupaten Lombok Barat, NTB, dengan berbagai pola kemitraan dalam usaha penggemukan sapi. Pola-pola kemitraan yang telah dikenal para peternak, diantaranya adalah pola bagi hasil. Pola ini, menurut hasil evaluasi, dikenal oleh seluruh (100\%) peternak peserta atau sasaran kegiatan. Pola kemitraan ternak sapi sistem bagi 
hasil (gaduhan) ini sudah dikenal lama oleh masyarakat pedesaan di Indonesia pada umumnya. Menurut Putranto (2016), gaduhan berasal dari kata gaduh yang diambil dari bahasa Jawa, secara sederhana dapat diartikan sebagai seseorang yang memberikan modal yang dimilikinya untuk dikembangkan orang lain. Gaduhan merupakan sistem bagi hasil antara pemilik modal dengan peternak. Orang yang mempunyai kehidupan ekonomi yang lebih mapan menitipkan ternaknya untuk dipelihara oleh petani/peternak. Hasil usaha dibagi sesuai dengan kesepakatan bersama antara pemilik modal dan peternak. Menurut Sumanto (2013), sistem ini memberikan keuntungan bagi pemilik modal maupun petani/peternak.

Strategi kemitraan dengan sistem bagi-hasil menunjukkan hubungan antara pemilik atau pihak/orang yang menggunakan (tanah, ternak, tanaman, dan lain-lain) dengan penggarap/penggaduh dan merupakan suatu bentuk usaha yang tidak mengeksploitasi sasaran usaha. Dilihat dari sudut ekonomi dan hukum, bagi hasil usaha ternak dapat berupa perjanjian upah, sebagai suatu bentuk perseroan, atau keduanya ; pada bagihasil usaha tambak akan ditambahkan lagi perjanjian sewa tambak.

Sistem bagi-hasil yang banyak diminati kalangan Landless Famers di desa Peresak Kecamatan Narmada, adalah sistem bagi-hasil dengan pola tradisional yang mendasarkan pada pembagian sama basar $(50: 50)$ terhadap pertambahan nilai modal (capital gain) sapi bakalan yang diusahakan. Pola demikian diketahui lebih menguntungkan bagi petani/peternak penggaduh dibanding pola bagi-hasil yang berkembang di daerah-daerah lain seperti Pola PIR di Bali yang mendasarkan pada pembagian nilai pertambahan bobot badan sapi (weight gain) 2/3 untuk penggaduh dan 1/3 untuk pemodal. Pada bagi-hasil pola tradisional, pendapatan petani/peternak penggaduh diperoleh tidak saja dari weight gain tetapi juga dari capital gain berupa pertambahan harga murni (PHM) dan kenaikan harga karena peningkatan kualitas (PHK). Sedangkan pada Pola PIR, semua Capital gain hanya dinikmati inti, padahal capital gain tersebut diperoleh ketika ternak dipelihara petani/peternak penggaduh (plasma).

Setiap pola bagi-hasil dalam usaha penggemukan sapi yang berkembang selama ini di Pulau Lombok diketahui sangat bermanfaat bagi kalangan Landless Famers, terutama dapat memberikan tambahan pendapatan (income generating) bagi keluarga mereka. Hal ini terlihat antara lain dari hasil evaluasi, bahwa persepsi peternak terhadap sistem bagi-hasil dalam penggemukan sapi di Desa Peresak Kecamatan Narmada adalah sangat positip, dalam hal itu, peternak penggaduh dapat memperoleh tambahan pendapatan rata-rata $\mathrm{Rp} 300.000$ per bulan dari setiap ekor sapi bakalan yang diusahakan. Matatula (2010) menyatakan bahwa pola bagi hasil (gaduhan) sapi potong rakyat merupakan salah satu model kemitraaan yang dapat digunakan untuk pengembangan usaha sapi potong dengan $\mathrm{B} / \mathrm{C}$ rasio selama 6 tahun mencapai 1,4 serta Internal rate of return (IRR) mencapai 30,87\% atau diatas tingkat disconto $12 \%$ yang berarti usaha yang "bankable".

Kegiatan penyuluhan yang telah dilakukan, juga telah dapat mengembangkan usaha penggemukan sapi rakyat berbasis kemitraan dengan penerapan sistem bagi-hasil, sebagai alternatif usaha income generating bagi kalangan Landless Famers di Desa Peresak Kecamatan Narmada Kabupaten Lombok Barat, NTB. Hasil evaluasi menunjukkan, dari 85 orang petani/peternak peserta kegiatan ini, 61 orang $(71,76 \%)$ diantaranya menyatakan ketertarikan dan kesediaan untuk mengembangkan usaha penggemukan sapi dengan pola kemitraan. Dari jumlah tersebut, tercatat 28 orang $(45,9 \%)$ telah memulai melaksanakan penggemukan sapi dengan pola bagi hasil. Sebagai mitra (pemodal), dalam hal ini, adalah pihak perorangan atau organisasi/institusi atau suatu badan usaha yang menunjukkan ketertarikan/hasrat secara sadar untuk menegembangkan usaha pada bidang penggemukan sapi, dan bersedia bermitra dengan peternak menurut tatacara atau pola yang disepakati bersama. Perorangan atau organisasi/institusi maupun badan usaha yang diutamakan untuk menjadi mitra para peternak sapi di Desa Peresak Kecamatan Narmada, adalah mereka yang pernah terlibat dalam usaha penggemukan sapi, baik secara mandiri maupun kemitraan, di Kecamatan Narmada dan sekitarnya. Penggalangan mitra ini dilakukan oleh tim dengan pendekatan persuasif dan melalui media seminar dan lokakarya (semiloka) melibatkan pihak-pihak pengusaha dan institusi serta instansi terkait seperti Koperasi Unit Desa, Dinas Peternakan, Perguruan Tinggi, dan lainnya. 
Adapaun tujuan kegiatan ini untuk menggalang kelompok-kelompok usaha penggemukan sapi berbasis kemitraan di Desa Peresak Kecamatan Narmada Kabupaten Lombok Barat, tampaknya belum bisa dicapai. Dalam hal ini, belum ada kelompok peternak penggemukan sapi berbasis kemitraan yang dapat tergalang selama pelaksanaan kegiatan ini. Para peternak sasaaran sementara ini lebih senang dan leluasa mengembangkan usaha ternaknya secara individu, dan belum siap untuk melakukan kolektifitas dalam wadah suatu kelompok. Namun demikian, menurut hasil evaluasi yang dilakukan, sebagian besar $(88,7 \%)$ peternak sasaran kegiatan yang sudah memulai usaha penggemukan sapi dengan pola bagi hasil, sangat berharap bisa bergabung dengan peternak penggemukan sapi lainnya di dusun yang sama dan mitra yang sama dalam satu kelompok kandang kolektif.

Berdasarkan hasil investigasi melalui FGD (Focus Group Discussion) melibatkan para peternak langsung, bahwa permasalahan yang dihadapi para peternak sapi di desa Peresak untuk mewujudkan adanya kelompok dimaksud, terutama, adalah tidak adanya lahan yang dapat digunakan untuk pengadaan kandang kolektif bagi kelompok. Meskipun cukup banyak tersedia lahan kosong di tiap dusun, namun para peternak yang jumlahnya masih terlalu sedikit untuk masing-masing dusun belum mampu membeli lahan yang cukup untuk kandang kolektip tersebut, walaupun mereka melakukan urunan untuk maksud itu. Sebagaimana diketahui, bahwa mereka (para peternak tersebut), adalah para petani lahan sempit dan buruh tani yang pendapatan hariannya sangat rendah.

Manfaat lainnya dari pelaksanaan pengabdian pada masyarakat ini, adalah membantu upaya pemerintah dalam pencapaian target Program Swasembada Daging Sapi (PSDS) yang tengah digalakkan di NTB. Pencapaian manfaat ini tampaknya bersifat jangka panjang, sehingga belum bisa diukur untuk saat ini. Namun demikian, harapan kearah itu bisa digambarkan dari adanya perkembangan jumlah usaha penggemukan sapi di masyarakat. Dalam hal ini, semakin banyak usaha penggemukan sapi yang berkembang di masyarakat maka semakin besar kemungkinan tercapainya Swasembada Daging Sapi yang dicanangkan pemerintah. Kegiatan ini juga diharapkan bermanfaat dalam mendukung upaya penyediaan sapi potong untuk perdagangan antar pulau yang mempersyaratkan standar bobot badan sapi $300 \mathrm{~kg}$, dan upaya mempertahankan peran daerah NTB sebagai salah satu sumber bibit dan daging sapi nasional.

\section{Faktor Pendorong dan Penghambat}

Beberapa faktor yang menjadi pendorong terlaksananya kegiatan Pengabdian pada Masyarakat ini, adalah : (1) Faktor yang berkaitan dengan pendorong bagi upaya pengembangan system produksi sapi potong berbasis kemitraan di desa Peresak, seperti belum berkembangnya sistem lembaga keuangan desa, bentuk usaha ternak masih bersifat keluarga, masih banyaknya keluarga yang berpendapatan rendah, dan desa yang bersangkutan memiliki potensi produksi yang cukup, (2) Program pemerintah dalam bidang peternakan, yang, salah satu diantaranya adalah Program Percepatan Swasembada Daging Sapi (P2SDS), (3) Peran aparat pemerintah setempat, terutama kepala desa beserta perangkatnya, yang sangat antusias dalam mendukung lancarnya pelaksanaan kegiatan ini, (4) Dukungan masyarakat, terutama para tokoh dan pemuka masyarakat setempat, berupa berbagai masukan sebagai bahan kajian dan pertimbangan bagi tim penyuluh, dukungan tenaga dan tempat, juga berupa peran serta dalam pengerahan massa, (5) Adanya kesadaran para peternak terhadap pentingnya ilmu pengetahuan dan teknologi dalam rangka meningkatkan keterampilan dan hasil beternak mereka. Hal ini cukup membantu dalam menghadirkan mereka untuk mengikuti kegiatan ini, dan yang terpenting adalah motivasi mereka untuk mengikuti kegiatan ini didasari oleh kebutuhan mereka terhadap pengetahuan dan teknologi, (6) Adanya kelembagaan petani/ peternak, antara lain kelompok-kelompok peternak kandang kolektif, keberadaannya sangat potensial sebagai media penyebaran informasi inovatif dalam masyarakat; kelembagaan yang ada, juga dapat menjadi sasaran strategis kegiatan pengabdian pada masyarakat, dan (7) Adanya balai atau berugaq di sekitar kandang lokasi kegiatan, dapat menjadi tempat berkumpul para peternak untuk membahas/mengembangkan informasi inovatif yang disuluhkan.

Adapun beberapa faktor yang dipandang sebagai penghambat kelancaran pelaksanaan kegiatan pengabdian pada masyarakat ini, adalah : (1) Rendahnya tingkat pendidikan rata-rata peternak yang menjadi sasaran kegiatan; sebagian 
besar petani/peternak tersebut $(56 \%)$ hanya berpendidikan SD bahkan terdapat $8 \%$ lainnya tidak berpendidikan dan tidak mampu baca tulis, $20 \%$ berpendidikan SLTP dan hanya 16\% berpendidikan SLTA. Hal ini menghambat proses adopsi pengetahuan dan teknologi yang disuluhkan, (2) Tidak tersedianya sarana listrik yang memadai di lokasi kegiatan, hal ini menghambat/membatasi tim penyuluh untuk menggunakan peralatan pendukung seperti LCD projector, (3) Kesempatan yang dimiliki tiap petani/peternak untuk mengikuti kegiatan ini tidak sama dan terbatas. Karena itu, waktu dan durasi pelaksanaan kegiatan ini menjadi sangat terbatas dan tidak optimum karena terpaksa mesti disesuaikan dengan keterbatasan kesempatan tersebut, (4) Masyarakat pada umumnya di lokasi kegiatan ini tampak telah terkondisi dengan proyekproyek pemberian bantuan sosial (bantuan material), sehingga kehadiran Tim Pengabdian pada Masyarakat di desa diasosiasikan dengan tim dari proyek sejenis yang datang membawa atau menjanjikan bantuan material.

\section{Kesimpulan}

Berdasarkan hasil yang dapat diinventarisir dalam kegiatan ini, dapat disimpulkan bahwa polapola kemitraan dalam penggemukan sapi telah dikenal oleh para peternak, yang sebagian besar $(62 \%)$ telah melaksanakan pola bagi hasil secara tradisional. Pengetahuan dan informasi yang disuluhkan, sangat membantu para peternak dalam mengatasi permasalahan rendahnya peluang kerja bagi masyarakat, serta dapat mengembangkan usaha penggemukan sapi rakyat dengan sistem kemitraan. Sebanyak 61 orang $(71,76 \%)$ peserta sasaran menyatakan ketertarikan dan kesediaan untuk mengembangkan usaha penggemukan sapi dengan pola kemitraan; dari jumlah tersebut, tercatat 28 orang $(45,9 \%)$ telah memulai melaksanakan penggemukan sapi dengan pola bagi hasil.

\section{Daftar Pustaka}

Badan Pusat Statistik. 2014. Nusa Tenggara Barat Dalam Angka 2014. Kantor Badan Pusat Statistik Provinsi Nusa Tenggara Barat, Mtr.

Bamualim, A., 2012. Strategi Penanggulangan Kemiskinan di Kawasan Timur Indonesia.
Maj. Studi Pembangunan Indonesia. 09(3):46-52.

Lole, U.R., 2000. Peluang Investasi dalam Sistem Bagi-Hasil Penggemukan Sapi di Kabupaten Belu Provinsi Nusa Tenggara Timur. J. Penel. Univ. Mataram, 1(3):2128.

Matatula, J.M., 2010. Analisis Finansial Usaha Peternakan Sapi Potong Pola Gaduhan di Kabupaten Seram. J. Agroforestry. 10 (2): 25-33.

Pribadi, L.W., 2004. Prosfek Penggemukan Sapi Berbasis Kemitraan di Kabupaten Lombok Barat. J. Pen.UNRAM. 2(1): 23-28.

Putranto, R., 2016. Analisis Keuntungan Peternakan Sapi Sistem Kemitraan (Gaduhan) di Kabupaten Magelang. ECCES, 3(2):1-31.

Scheltema, T.B., 1995. The Prospect of Traditional Animal Production System in Indonesia. DAP Bull. 33(12):551-558.

Simatupang, P., 1993. Analisis Ekonomi Perbandingan Sistem Bagi Hasil Usaha Ternak Sapi Potong Pola PIR dengan Gaduhan Tradisional di Propinsi Bali. Lokakarya Nasional Program Agroindustri. IPB, Bogor.

Simatupang, P., 2013. Sosiologi Landless Farmers di Indonesia. Dalam: Prosfektus Sumberdaya Manusia Indonesia, Suatu Kajian Sosiologis. A. Sasono dan Y. Annaf (Eds.). LSP Pub., Jkt.

Sulmawati, S., 2008. Persepsi Peternak Terhadap Pola Bagi Hasil dalam Usaha Penggemukan Sapi Rakyat di Nusa Tenggara Barat. Lap. Pen. Lembaga Pen. Universitas Mataram, Mataram.

Sumanto, 2013. Pemberdayaan Peternak Sapi Potong Melalui Kemitraan Bagi Hasil di Kalimantan. Pros. Seminar Nasional Peternakan dan Veteriner. Balitnak, Bogor.

Zaini, A., 2008. Peranan Peternakan Rakyat dalam Penanggulangan Kemiskinan di Nusa Tenggara Barat. Maj.Ilmiah ORYZA Univ. Mataram. 4(2):27-34. 